Article

\title{
Alleviation of Cadmium Stress in Wheat through the Combined Application of Boron and Biochar via Regulating Morpho-Physiological and Antioxidant Defense Mechanisms
}

\author{
Sajjad Hussain 1, Muhammad Irfan ${ }^{2} \mathbb{D}$, Abdul Sattar ${ }^{3, *}$, Shabir Hussain ${ }^{2}$, Sami Ullah ${ }^{4}$, Tahira Abbas ${ }^{3}$, \\ Haseeb Ur-Rehman ${ }^{2}$, Farukh Nawaz ${ }^{3}$, Abdulrahman Al-Hashimi ${ }^{5}$ D, Mohamed S. Elshikh ${ }^{5}$, Mumtaz Cheema ${ }^{6}$ \\ and Jianjun Yang $1, *(\mathbb{D}$
}

check for updates

Citation: Hussain, S.; Irfan, M.; Sattar,

A.; Hussain, S.; Ullah, S.; Abbas, T.;

Ur-Rehman, H.; Nawaz, F.;

Al-Hashimi, A.; Elshikh, M.S.; et al Alleviation of Cadmium Stress in Wheat through the Combined Application of Boron and Biochar via Regulating Morpho-Physiological and Antioxidant Defense

Mechanisms. Agronomy 2022, 12, 434. https://doi.org/10.3390/ agronomy12020434

Academic Editor: Pilar Soengas

Received: 26 November 2021

Accepted: 1 February 2022

Published: 9 February 2022

Publisher's Note: MDPI stays neutral with regard to jurisdictional claims in published maps and institutional affiliations.

Copyright: (C) 2022 by the authors. Licensee MDPI, Basel, Switzerland. This article is an open access article distributed under the terms and conditions of the Creative Commons Attribution (CC BY) license (https:// creativecommons.org/licenses/by/ $4.0 /)$.
1 Institute of Environment and Sustainable Development in Agriculture, Chinese Academy of Agricultural Sciences, Beijing 100081, China; sajjad.husains786@gmail.com

2 Department of Agronomy, Faculty of Agriculture Sciences and Technology, Baha Uddin Zakariya University, Multan 60800, Pakistan; muhammad.irfan26@gmail.com (M.I.); hussainuaf@gmail.com (S.H.); haseeb_khar@hotmail.com (H.U.-R.)

3 College of Agriculture, Bahadur Sub-Campus, Baha Uddin Zakariya University, Layyah 32200, Pakistan; dr.ta92@bzu.edu.pk (T.A.); farukhnawaz07@gmail.com (F.N.)

4 Department of Horticulture, MNS-University of Agriculture, Multan 66000, Pakistan; sami.ullah65@gmail.com

5 Department of Botany and Microbiology, College of Science, King Saud University, Riyadh 12372, Saudi Arabia; aalhashimi@ksu.edu.sa (A.A.-H.); melshikh@ksu.edu.sa (M.S.E.)

6 School of Science and the Environment, Grenfell Campus, Memorial University of Newfoundland, Corner Brook, NL A2H 5G4, Canada; mcheema@grenfell.mun.ca

* Correspondence: abdulsattar04@gmail.com (A.S.); yangjianjun@caas.cn (J.Y.); Tel.: +92-333-6665-575 (A.S.); +86-018-2105-996 (J.Y.)

Abstract: Cadmium (Cd) contamination in soil adversely affects crop productivity, grain quality, and human health. Applications of boron (B) and biochar are known to impart tolerance to crops against abiotic stresses. A pot experiment was performed to assess the effects of the sole and combined application of $\mathrm{B}$ and biochar on growth, physiological and antioxidant defense mechanisms, yield, and grain quality of wheat under Cd toxicity-induced stress. The treatments included control $\left(0 \mathrm{mg} \mathrm{kg}^{-1}\right.$ and $\left.0 \mathrm{~g} \mathrm{~kg}^{-1}\right)$, only $\mathrm{Cd}\left(15 \mathrm{mg} \mathrm{kg}^{-1}\right)$, only B $\left(5 \mathrm{~g} \mathrm{~kg}^{-1}\right)$, only biochar $\left(50 \mathrm{~g} \mathrm{~kg}^{-1}\right)$, B plus biochar, Cd plus B, Cd plus biochar, and Cd plus B plus biochar, which were applied at the time of sowing and were arranged using completely randomized design (CRD) with five replications. The individual Cd toxicity (15 $\mathrm{mg} \mathrm{kg}^{-1}$ ) significantly reduced $\mathrm{chl} \mathrm{a,} \mathrm{chl} \mathrm{b,} \mathrm{and} \mathrm{chl} \mathrm{a+b,} \mathrm{as} \mathrm{well} \mathrm{as} \mathrm{primary} \mathrm{metabolites}$ (soluble protein, amino acids, total soluble sugar, and phenolic contents), while it increased the activities of enzymatic antioxidants like superoxide dismutase (SOD), peroxidase (POD), catalase (CAT), and ascorbate peroxidase (APX) in the leaves of wheat. In addition, Cd stress $\left(15 \mathrm{mg} \mathrm{kg}^{-1}\right)$ increased lipid peroxidation in the form of malondialdehyde (MDA), and it enhanced the hydrogen peroxide $\left(\mathrm{H}_{2} \mathrm{O}_{2}\right)$ content, electrolyte leakage (EL), and proline contents in the leaves. Furthermore, $\mathrm{Cd}$ $\left(15 \mathrm{mg} \mathrm{kg}^{-1}\right)$ contamination reduced the grain yield and yield-related attributes relative to respective no-Cd treatments. Soil-applied B and biochar improved wheat grain yield by triggering the activities of enzymatic antioxidants. Individual or combined B and biochar applications improved proline contents and reduced $\mathrm{H}_{2} \mathrm{O}_{2}$ and MDA contents in plants. The combined application of $\mathrm{B}$ and biochar enhanced soluble sugars and total phenolic as compared to the control and Cd-contaminated plants. In conclusion, the combined application of B and biochar was found to be the best soil amendment strategy to improve the yield of wheat under Cd-contaminated soil.

Keywords: antioxidants; biochar; boron; cadmium toxicity; lipid peroxidation; productivity 


\section{Introduction}

Cadmium $(\mathrm{Cd})$ is one of the main hazardous elements and is generally considered the most toxic element in cereal crops [1]. For instance, $\mathrm{Cd}$ toxicity hinders the growth and development of plants, which ultimately reduces their morphological and yield attributes. Therefore, the application of $\mathrm{Cd}$ disrupts the development of plants and decreases their structure characteristics, morphological properties, and dry biomass production [2]. Cadmium (Cd) affects the physiochemical and biological processes in plants which ultimately disrupt plants vegetative growth and development, leading to decreased grain yields and lowered grain quality [3]. Moreover, cadmium (Cd) induced oxidative stress hinders antioxidant defense systems in crop plants [4]. Due to cadmium (Cd) stress in plants, reactive oxygen species (ROS) are produced, which stimulate antioxidant defense systems [5,6]. Antioxidants like catalase (CAT), ascorbate peroxidase (APX), superoxide dismutase (SOD), and peroxidase (POD) detoxified the adverse effects of reactive oxygen species in wheat grown under Cd-contaminated soil [7]. Severe oxidative damage was observed in crops due to enhanced ROS production [3]. Furthermore, antioxidant enzymatic processes were reduced due to cadmium $(\mathrm{Cd})$ toxicity in wheat crops [8]. Globally, wheat (Triticum aestivum L.) is the leading cereal crop and is an important staple food. Hence, heavy metal contaminations, particularly that of $\mathrm{Cd}$, create deleterious effects on human health because of their translocation and accumulation in cereal grains [9,10]. Similarly, the accumulation of $\mathrm{Cd}$ in plant cells impairs the plant's physiological and metabolic processes due to the possibility of imbalance in nutrient uptake, interrupting energy production [11].

Boron (B) is an important micronutrient necessary for crop growth and development, and it plays a significant role in improving plant's physiological attributes [12]. It plays a primary role in the physiological and biochemical activities of cell membranes, photosynthesis, cell division and elongation, nitrogen use efficiency, and in improving the sugar contents of plants [13]. B inadequacy influences different structural and functional activities of a plant's vascular bundles, for example, root initiation, translocation of sugar contents, and starch and nitrogen digestion [14]. B assumes a key part in a plant's cell wall, where $70-90 \%$ of the total copper, zinc, and Cd are situated in certain plants [15]. It enhances the probability of tweaking $\mathrm{Cd}$ accumulation and poisonousness. Hence, Boron (B) eases plant cadmium poisonousness due to retreating cadmium aggregation and relieving oxidative stress which was produced due to cadmium induction [16]. The cadmium adsorption in Brassica napus was improved due to the cell wall, which was an integral part, and it forestalls cadmium exit from the cell through the cell wall, and Cd chelates on the cell wall [17]. Likewise, boron is also engaged in the formation and cross-linking of different cell wall parts [18]. Therefore, it might be assumed that cadmium aggregation and toxicity management may be helpful for successful crop growth.

Yet, there is a lack of information to support the ability of boron to enable plants to survive under cadmium toxicity. In spite of the expanding considerations on the interaction of cadmium with different biochemical cycles in plants, less data exists on the association of cadmium with fundamental microelements. One more methodology for remediating metal-contaminated soils is immobilization; the utilization of biochar is an eco-accommodating and affordable immobilizer for substantial metal pollution [19]. The amendment of biochar added through soil facilitates heavy metal stabilization via different processes, such as surface complexation, adsorption, and metal exchange [20]. In rice crops, $\mathrm{Cd}$ immobilization into a more steady form diminishes metal substances and also diminishes bioavailable parts due to the application of biochar. Another study reported that the use of biochar treated with acid enhanced the growth, development, and gas exchange characteristics of quinoa by lowering the accumulation of heavy metals in various plant parts, such as the roots, shoots, and grains of quinoa [21].

Although there are various research articles on the use of boron [15] or biochar as an individual application [22] to lower the bioavailability of metals and enhance crop growth and development; however, there is no literature about the combined use of B and biochar to reduce the $\mathrm{Cd}$ toxicity in plants. Therefore, in this study, we planned to evaluate the 
effects of B and soil-applied biochar, individually or combined, on the morphological, physiochemical, and biological traits of wheat grown under $\mathrm{Cd}$ toxicity.

\section{Materials and Methods}

\subsection{Experimental Conditions and Design}

The current experiment was carried out in earthen pots in open conditions at Baha-Uddin Zakariya University, Layyah Campus, Pakistan during winter 2020 to assess the individual and combined effects of boron and biochar to mitigate the adversities of cadmium toxicity in wheat crop. Ten (10) healthy and uniform-sized seeds of the wheat variety Fakhar-eBhakhar-2019 were planted in each pot directly and filled with soil to avoid germination losses. After seven days of germination, thinning was done, and only five plants were kept in each pot to maintain optimum plant populations. Each earthen pot was $16 \mathrm{~cm}$ in diameter and $45 \mathrm{~cm}$ in height, and they were filled with $15 \mathrm{~kg}$ of sandy loam soil. For better crop growth and development, $0.08,0.06$, and $0.05 \mathrm{~g} \mathrm{~N}, \mathrm{P}$, and $\mathrm{K}$, respectively, (in the form of urea $46 \% \mathrm{~N}$, DAP $46 \% \mathrm{P}_{2} \mathrm{O}_{5}$, and MOP $60 \% \mathrm{~K}_{2} \mathrm{O} \mathrm{kg}^{-1}$ of soil) were mixed in the soil at the time of sowing by the soil mass method. Treatments, comprised of the control, only $\mathrm{Cd}$ $\left(15 \mathrm{mg} \mathrm{kg}^{-1}\right)$, only B $\left(5 \mathrm{~g} \mathrm{~kg}^{-1}\right)$, only biochar $\left(50 \mathrm{~g} \mathrm{~kg}^{-1}\right), \mathrm{B}+$ biochar $\left(5 \mathrm{~g} \mathrm{~kg}^{-1}+50 \mathrm{~g} \mathrm{~kg}^{-1}\right)$, $\mathrm{Cd}+\mathrm{B}\left(10 \mathrm{mg} \mathrm{kg}^{-1}+5 \mathrm{~g} \mathrm{~kg}^{-1}\right), \mathrm{Cd}+$ biochar $\left(10 \mathrm{mg} \mathrm{kg}^{-1}+50 \mathrm{~g} \mathrm{~kg}^{-1}\right)$, and $\mathrm{Cd}+\mathrm{B}+$ biochar $\left(10 \mathrm{mg} \mathrm{kg}^{-1}+5 \mathrm{~g} \mathrm{~kg}^{-1}+50 \mathrm{~g} \mathrm{~kg}^{-1}\right.$ soil) were thoroughly mixed in sandy loam soil at the time of planting. These experimental treatments were arranged using completely randomized design (CRD) with five replications. There was a total 40 experimental units ( 8 treatments $\times 5$ replications) in the experiment. Each replication contained three pots having five plants in each pot. Boron and biochar were mixed thoroughly, individually or combined, according to treatments. Cadmium stress was induced by spiking the soil using analytical grade cadmium chloride $\left(\mathrm{CdCl}_{2}\right)$.

\subsection{Preparation of Rice Straw Biochar}

Biochar was prepared by using rice straw according to the method of Qayyum et al., 2015 [23]. Rice straw was put in the biochar machine for pyrolysis at $500{ }^{\circ} \mathrm{C}$ in anaerobic conditions. After $40 \mathrm{~min}$, pyrolysed biochar was taken from the machines and passed through a sieve $(2 \mathrm{~mm})$ after crushing. Chemical properties of the rice straw biochar are given in Table S1.

\subsection{Morphological and Yield-Related Attributes}

Seventy-five DAS days after sowing, five plants were randomly selected from each treatment. Leaf samples were collected from each plant and leaf area was measured with the help of a leaf area meter (CI-203CA Leaf Conveyor; 1554 NE 3rd Ave Camas, WA, USA). Upon reaching maturity, five plants were selected randomly, and plant height was measured from the ground to the tip of the plant using a meter rod. Spikes from the selected plants were separated with the help of scissors and spike length was measured with a measuring tape. The numbers of grains per spike were counted from five randomly selected spikes from each treatment after manually threshing the spike and grain yield and 100-grain weight were calculated. The 100 seeds were counted with a digital seed counter from each replication, then these seeds were weighed on an electric balance to calculate 100-grain weight and their average weight was calculated. For measuring the grain yield, seeds were cleaned from each replication, then weighed, and the average per plant was calculated.

\subsection{Determination Photosynthetic Pigments}

Photosynthetic pigments (chlorophyll a, chlorophyll b, and carotenoid) were determined by using an extract of $0.5 \mathrm{~g}$ of fresh leaves. Leaf extract was obtained by keeping the leaves in $5 \mathrm{~mL}$ of $80 \%$ acetone for $24 \mathrm{~h}$. Extracts were then centrifuged at $10,000 \times g$. Chlorophyll $\mathrm{a}$, chlorophyll $\mathrm{b}$, and carotenoid contents were determined by taking the 
absorbance reading of supernatant samples at 645,663 , and $480 \mathrm{~nm}$, respectively, with a spectrophotometer [24].

\subsection{Extraction of Enzymes}

For protein and antioxidant enzyme assays, frozen leaves were ground to a fine powder with liquid nitrogen and were extracted with ice-cold $0.1 \mathrm{M}$ Tris- $\mathrm{HCl}$ buffer $(\mathrm{pH}$ $7.5)$ containing $5 \%(w / v)$ sucrose and $0.1 \% 2$-mercaptoethanol (3:1 buffer volume/FW). The homogenate was centrifuged at $10,000 \mathrm{~g}$ for $20 \mathrm{~min}$ at $4{ }^{\circ} \mathrm{C}$, and the supernatant was used for enzyme activity and protein determinations. Preparations for enzyme extraction and enzyme assay were carried out at $4{ }^{\circ} \mathrm{C}$.

\subsubsection{Determination of Primary Metabolites}

Total soluble proteins in the leaf sample were determined through Bradford [25] assay by using Coomassie Blue dye. The $100 \mu \mathrm{L}$ leaf sample and $2 \mathrm{~mL}$ Bradford reagent were mixed in the test tube. The mixture was incubated for $20 \mathrm{~min}$ in the dark and the absorbance reading was determined at $595 \mathrm{~nm}$. In $50 \mathrm{mM}$ chilled potassium phosphate buffer $(5 \mathrm{~mL}$; $\mathrm{pH} 7.5)$, fresh leaf tissues $(0.2 \mathrm{~g})$ were homogenized and centrifuged for $20 \mathrm{~min}$ at $10,000 \times \mathrm{g}$. In a test tube, equal volumes of $10 \%$ pyridine and acid ninhydrin were homogenized with $1 \mathrm{~mL}$ of supernatant. After that, heat was given at $95^{\circ} \mathrm{C}$ to the reaction mixture for $30 \mathrm{~min}$ using a water bath. Then, by using distilled water, the volume of the reaction mixture was raised up to $7.5 \mathrm{~mL}$. Finally, at $570 \mathrm{~nm}$, absorbance of the reaction mixture was observed [26].

In order to measure the total soluble sugars, $5 \mathrm{~mL}$ of aqueous ethanol $(80 \%)$ and $0.2-\mathrm{g}$ of fresh leaf tissues were homogenized, then centrifuged for $10 \mathrm{~min}$ at $3500 \mathrm{~g}$. The sample extract $(100 \mu \mathrm{L})$ obtained was then reacted with enthrone reagent $(3 \mathrm{~mL})$. Then, by using a water bath, the mixture was heated for $10 \mathrm{~min}$ at $95^{\circ} \mathrm{C}$. The mixture was then cooled and, using a spectrophotometer, absorbance was observed at $625 \mathrm{~nm}$ [27]. By using the method of Julkenen-Titto [28], the total phenolic contents of fresh leaf samples were determined. For this purpose, $1 \mathrm{~mL}$ of acetone (80\%) and $0.2 \mathrm{~g}$ of fresh leaf tissues were homogenized. They were then centrifuged at 12,000 rpm for $15 \mathrm{~min}$, then $20 \% \mathrm{Na}_{2} \mathrm{CO}_{3}(2.5 \mathrm{~mL}), 0.5-\mathrm{mL}$ Folin-Ciocalteu phenol re-agent, and supernatant $(100 \mu \mathrm{L})$ were added to the test tube, and it was shaken. Then, in order to make a $5 \mathrm{~mL}$ final volume, distilled water was added. Lastly, absorbance was recorded at $750 \mathrm{~nm}$ after $20 \mathrm{~min}$.

\subsubsection{Determination of Enzymatic Antioxidant Activities}

SOD activity assay was based on the method of Dhindsa et al [29], which is based on the measurement of inhibition in the photochemical reduction of nitro blue tetrazolium (NBT) spectrophotometrically at $560 \mathrm{~nm}$. The reaction mixture contained $50 \mathrm{mM}$ K-phosphate buffer (pH 7.8), 13 mM methionine, $75 \mu \mathrm{M}$ NBT, $0.1 \mu \mathrm{M}$ EDTA, $4 \mu \mathrm{M}$ riboflavin, and the required amount of enzyme extract. The reaction was started by adding riboflavin and placing the tubes under two $15 \mathrm{~W}$ fluorescent lamps for $15 \mathrm{~min}$. A complete reaction mixture without enzyme, which gave the maximal colour, served as the control. A non-irradiated, complete reaction mixture served as a blank. One unit of SOD activity was defined as the amount of enzyme required to cause $50 \%$ inhibition of the reduction of NBT as monitored at $560 \mathrm{~nm}$, which was measured according to the method of Giannopolitis and Ries [30]. POD activity was determined at $436 \mathrm{~nm}$ by its ability to convert guaiacol to tetra guaiacol $\left(\varepsilon=26.6 \mathrm{mM}^{-1} \mathrm{~cm}^{-1}\right)$, according to the method of Polle et al. [31]. The reaction mixture contained $100 \mathrm{mM} \mathrm{K-phosphate} \mathrm{buffer} \mathrm{(pH} \mathrm{7.0),} 20.1 \mathrm{mM}$ guaiacol, $10 \mathrm{mM}$ $\mathrm{H}_{2} \mathrm{O}_{2}$, and enzyme extract. The increase in absorbance was recorded by the addition of $\mathrm{H}_{2} \mathrm{O}_{2}$ at $436 \mathrm{~nm}$ for $5 \mathrm{~min}$. CAT activity was determined by monitoring the disappearance of $\mathrm{H}_{2} \mathrm{O}_{2}$ at $240 \mathrm{~nm}\left(\varepsilon=40 \mathrm{mM}^{-1} \mathrm{~cm}^{-1}\right)$, according to the method of Aebi [32]. The reaction mixture contained $50 \mathrm{mM} \mathrm{K-phosphate} \mathrm{buffer} \mathrm{(} \mathrm{pH}$ 7.0).

In order to determine $\mathrm{H}_{2} \mathrm{O}_{2}$ content, $1.5 \mathrm{~mL}$ of trichloroacetic acid $(0.1 \%)$ and fresh leaf tissue $(0.15 \mathrm{~g})$ were homogenized. Then, centrifugation of the homogenate was done at 
$12,000 \times g$ for $15 \mathrm{~min}$. Then, $0.5 \mathrm{~mL}$ of potassium sulfate buffer $(10 \mathrm{mM}, \mathrm{pH} 7.0)$ and $1 \mathrm{~mL}$ of potassium iodide were added to supernatant. At $390 \mathrm{~nm}$, using a spectrophotometer, absorbance of the reaction mixture and trichloroacetic acid $(0.1 \%)$ was observed. By doing comparison of the absorbance with a standard curve, the amount of $\mathrm{H}_{2} \mathrm{O}_{2}$ content was measured [33].

\subsection{MDA Determination}

Hodges et al. [34] described a method called the TBA method. Utilizing this method, the amount of MDA content was measured. For the purpose of analysis, fresh leaves $(0.15 \mathrm{~g})$ of wheat were ground with $5.0 \mathrm{~mL}$ of $5 \%(w / v)$ TCA. This was done in a mortar that was placed an ice bath, and then centrifugation was done. Then, by using a spectrophotometer, MDA content was measured at $600 \mathrm{~nm}$ and at $532 \mathrm{~nm}$. For measuring the proline content, $5 \mathrm{~mL}$ sulpho-salicylic acid $(3 \%)$ and fresh leaf tissue $(0.1 \mathrm{~g})$ were homogenized. Then, the homogenate was centrifuged. Then, ninhydrin and glacial acetic acid reagent were added to supernatant. By using a water bath, $1 \mathrm{~h}$ boiling of the reaction mixture was done. After boiling, the reaction mixture was cooled for $10 \mathrm{~min}$ in an ice bath. Using a spectrophotometer, absorbance was measured at $520 \mathrm{~nm}$ and proline was extracted from the mixture with toluene [35].

\subsection{Determination of Electrolytic Leakage}

Using the method of Dionisio-Sese and Tobita [36], electrolyte leakage was measured. In a test tube, $10 \mathrm{~mL}$ distilled water and small and equal sized pieces of fresh leaf tissue $(0.5 \mathrm{~g})$ were added and stirred for $10 \mathrm{~s}$. The test tubes were then left overnight, and electrical conductivity $\left(\mathrm{EC}_{1}\right)$ was calculated. For measuring the $\mathrm{EC}_{2}$, test tubes were autoclaved at $100{ }^{\circ} \mathrm{C}$ for $1 \mathrm{~h}$.

\subsection{Data Analysis}

Statistical analysis of data was done with the help of Statistix 8.1 software (Analytical Software, Statistix; Tallahassee, FL, USA, 1985-2003) by using analysis of variance (ANOVA) techniques. For mean separation at the 5\% probability level, Tukey's test was used. The graphical presentation of data was done by using Sigma Plot.

\section{Results}

\subsection{Plant Height, Yield, and Yield Components}

Cadmium stress had a drastic effect on plant growth parameters, and it significantly reduced plant height by $16.57 \%$, spike length by $15.58 \%$, grains per spike by $16.43 \%, 100$ grain weight by $14.54 \%$, and grain yield per plant by $16.33 \%$, as compared to the control (Figures 1 and 2). The applications of solely boron or biochar, and their combination, significantly affected the plants growth parameters. Under the cadmium stress condition, boron application enhanced plant height by $4.34 \%$, spike length by $8.19 \%$, grains per spike by $4.76 \%$, 100-grain weight by $7.97 \%$, and grain yield per plant by $10.10 \%$ and biochar application enhanced plant height by $3.01 \%$, spike length by $5.86 \%$, grains per spike by $10.77 \%, 100$-grain weight by $12.50 \%$, and grain yield per plant by $14.81 \%$ (Figures 1 and 2 ). Likewise, the combined application of boron and biochar enhanced plant height by $5.34 \%$, spike length by $12.34 \%$, grains per spike by $13.75 \%, 100$-grain weight by $15.51 \%$, and grain yield per plant by $16.83 \%$ under cadmium stress conditions (Figures 1 and 2 ). The maximum results were observed when the combined application of boron and biochar was done on wheat plants. 

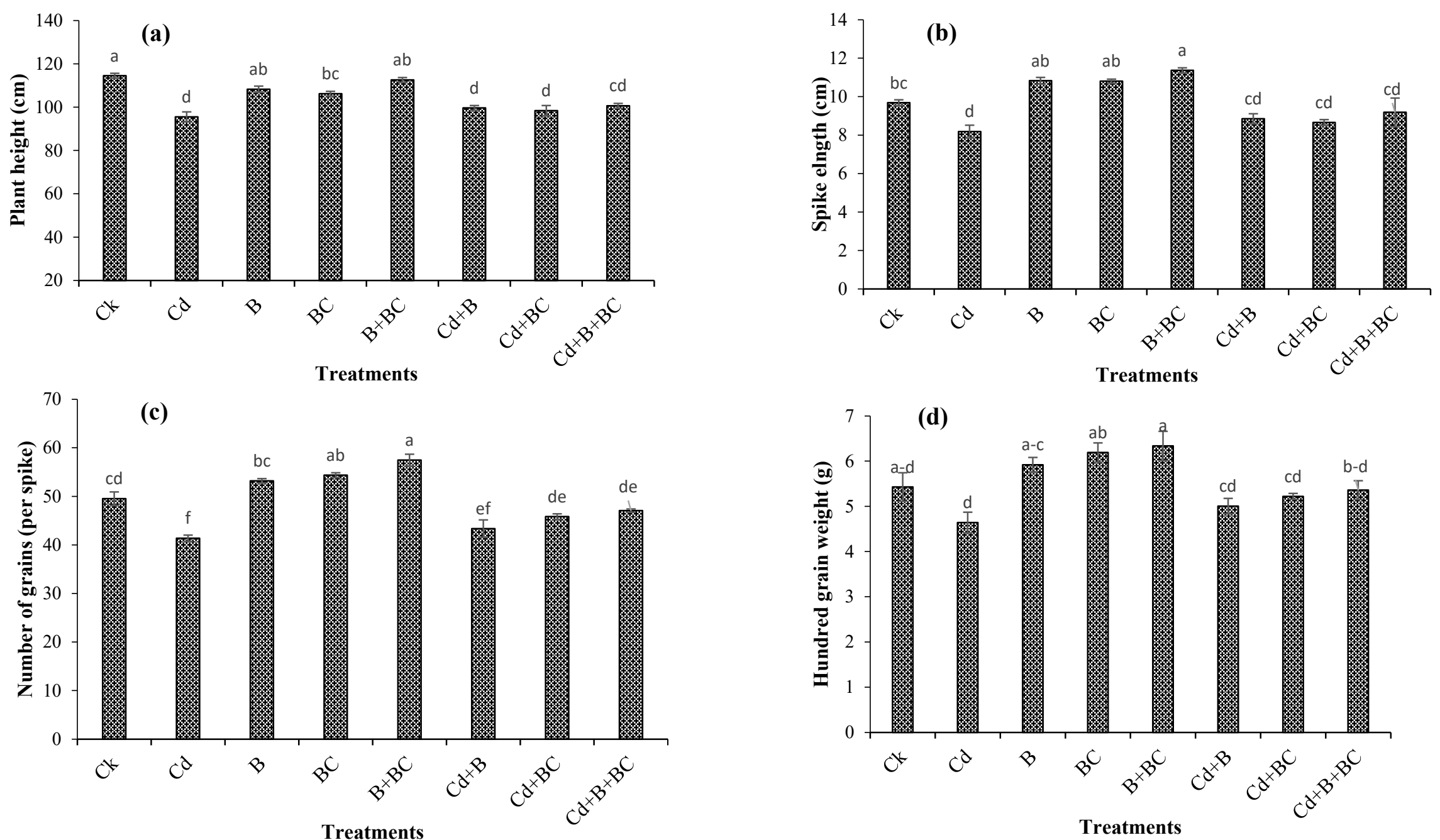

Figure 1. The influence of boron and biochar on plant height (a), spike length (b), number of grains (c), and 100-grain weight (d) of wheat under $\mathrm{Cd}$ stress, $\mathrm{Ck}$ control, $\mathrm{Cd}$ control stress, $\mathrm{B}$ boron, $\mathrm{BC}$ biochar, $\mathrm{B}+\mathrm{BC}$ boron and biochar, $\mathrm{Cd}+\mathrm{B}$ cadmium and Boron, $\mathrm{Cd}+\mathrm{BC}$ cadmium and biochar and $\mathrm{Cd}+\mathrm{B}+\mathrm{BC}$ cadmium, boron and biochar. Different letters above the column indicate significance level among the treatments. 


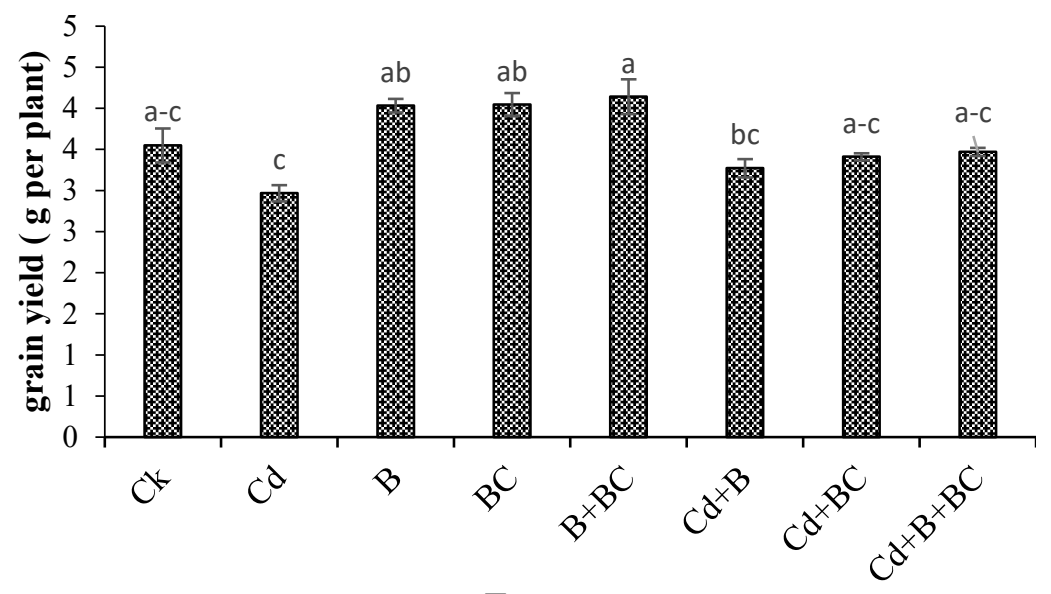

Treatments

Figure 2. The influence of boron and biochar on the grain yield of wheat under $\mathrm{Cd}$ stress, $\mathrm{Ck}$ control, $\mathrm{Cd}$ control stress, $\mathrm{B}$ boron, $\mathrm{BC}$ biochar, $\mathrm{B}+\mathrm{BC}$ boron and biochar, $\mathrm{Cd}+\mathrm{B}$ cadmium and Boron, $\mathrm{Cd}+\mathrm{BC}$ cadmium and biochar and $\mathrm{Cd}+\mathrm{B}+\mathrm{BC}$ cadmium, boron, and biochar. Different letters above the column indicate significance level among the treatments.

\subsection{Photosynthetic Pigments}

Photosynthetic pigments (chl. a, chl. b, chl. a+b, chl. a/b, and carotenoid) of flag leaves were measured at the heading stage. In the absence of $\mathrm{Cd}$ stress, boron application enhanced $14.81 \% \mathrm{chl} a, 18.51 \% \mathrm{chl} b, 15.74 \% \mathrm{chl} a+\mathrm{b}, 3.98 \% \mathrm{chl} \mathrm{a} / \mathrm{b}$, and $17.64 \%$ carotenoid, while the biochar application enhanced $13.16 \%$ chl a, $6.17 \% \mathrm{chl} b, 11.41 \% \mathrm{chl} a+b$, and $6.64 \%$ $\mathrm{chl} \mathrm{a} / \mathrm{b}$ as compared to individual $\mathrm{Cd}$ stress treatment. The sole application of biochar did not show any significant effect on carotenoid. However, the combination of both boron and biochar resulted in maximum activity and enhanced $22.22 \% \mathrm{chl}$ a, $27.16 \% \mathrm{chl}$ b $23.45 \%$ $\mathrm{chl} \mathrm{a}+\mathrm{b}$, and $29.41 \%$ carotenoid as compared to the control, and chlorophyll a/b contents were reduced up to $4.65 \%$ when biochar was applied. However, when cadmium stress was imposed, it drastically decreased the content of photosynthetic pigments. It reduced $4.52 \%$ chl a, $25.92 \% \mathrm{chl} \mathrm{b}, 9.87 \% \mathrm{chl} \mathrm{a}+\mathrm{b}$, and $23.52 \%$ carotenoid content and chlorophyll $\mathrm{a} / \mathrm{b}$ content were increased under $\mathrm{Cd}$ stress by $27.90 \%$. The boron and biochar application on Cd-treated plants showed an almost similar effect with one another and enhanced $9.48 \%$ chl a, $20.0 \%$ chl b, $11.64 \%$ chl a $+b$, and $15.38 \%$ carotenoid as compared to Cd-treated plants. The combined application of biochar and boron on Cd-stressed plants enhanced $14.65 \% \mathrm{chl}$ a, $23.33 \%$ chl b, $16.09 \%$ chl a $+b$, and $23.07 \%$ carotenoid as compared to Cd-stressed plants. There was a declined effect of boron and biochar and their combination on chlorophyll $\mathrm{a} / \mathrm{b}$ under cadmium stress (Table 1).

\subsection{Enzymatic Antioxidants Activities}

It was observed that application of only boron on wheat plants enhanced antioxidant activity as compared to the control condition. SOD, CAT, POD, and ascorbate peroxidase activities were improved by $17.03 \%, 20.57 \%, 13.53 \%$, and $8.51 \%$, respectively, as compared to the control. Biochar application enhanced $23.59 \%$ SOD, $9.59 \%$ CAT, $8.15 \%$ POD, and $10.63 \%$ ascorbate peroxidase as compared to control. However, when combined application of boron and biochar was done, it showed maximum results and increased $37.60 \%$ SOD, $13.25 \%$ CAT, $7.23 \%$ POD, and $19.14 \%$ ascorbate peroxidase as compared to control. In comparison, when cadmium stress was imposed, it boosted the antioxidant activity even much more than those plants where application of boron and biochar was done and increased $61.56 \%$ SOD, $60.12 \%$ CAT, $43.07 \%$ POD, and $90.42 \%$ ascorbate peroxidase as compared to the control. When boron was applied on Cd-treated plants, it enhanced $94.02 \% \mathrm{SOD}, 8.78 \%$ CAT, $25.48 \%$ POD, and $22.90 \%$ ascorbate peroxidase activity as compared to control, and the application of biochar on Cd-treated plants resulted in $32.25 \%, 2.06 \%, 14.73 \%$, and $7.82 \%$ 
increases in SOD, CAT, POD, and ascorbate peroxidase activity, respectively as compared to individual application of $\mathrm{Cd}$. The combination of boron and biochar showed maximum results and enhanced 51.57\% SOD, $24.16 \%$ CAT, 32.58\% POD, and $41.34 \%$ ascorbate peroxidase activity as compared to Cd-stressed plants (Table 2).

Table 1. The influence of the individual and combined applications of boron and biochar on the photosynthetic pigments of wheat leaves under cadmium stress.

\begin{tabular}{|c|c|c|c|c|c|}
\hline Treatments & $\begin{array}{l}\text { Chlorophyll a } \\
\quad\left(\mathrm{mg} \mathrm{g}^{-1}\right)\end{array}$ & $\begin{array}{l}\text { Chlorophyll b } \\
\left(\mathrm{mg} \mathrm{g}^{-1}\right)\end{array}$ & $\begin{array}{l}\text { Chlorophyll } a+b \\
\left(\mathrm{mg} \mathrm{g}^{-1}\right)\end{array}$ & Chlorophyll a/b & $\begin{array}{l}\text { Total Carotenoid } \\
\quad\left(\mathrm{mg} \mathrm{g}^{-1}\right)\end{array}$ \\
\hline Control (ck) & $2.43 \pm 0.02 \mathrm{e}$ & $0.81 \pm 0.017 \mathrm{~d}$ & $3.24 \pm 0.037 \mathrm{e}$ & $3.01 \pm 0.039 \mathrm{~cd}$ & $0.17 \pm 0.003 c$ \\
\hline Cadmium $(\mathrm{Cd})$ & $2.32 \pm 0.01 \mathrm{f}$ & $0.60 \pm 0.020 \mathrm{~g}$ & $2.92 \pm 0.015 \mathrm{f}$ & $3.85 \pm 0.013 \mathrm{a}$ & $0.13 \pm 0.004 \mathrm{e}$ \\
\hline Boron (B) & $2.79 \pm 0.01 b$ & $0.96 \pm 0.011 b$ & $3.75 \pm 0.025 b$ & $2.89 \pm 0.027 \mathrm{~d}$ & $0.20 \pm 0.002 b$ \\
\hline Biochar (Bc) & $2.75 \pm 0.02 \mathrm{~b}$ & $0.86 \pm 0.006 c$ & $3.61 \pm 0.017 c$ & $3.21 \pm 0.050 \mathrm{c}$ & $0.18 \pm 0.003 c$ \\
\hline $\mathrm{B}+\mathrm{Bc}$ & $2.97 \pm 0.03 \mathrm{a}$ & $1.03 \pm 0.008 \mathrm{a}$ & $4.00 \pm 0.023 \mathrm{a}$ & $2.87 \pm 0.055 \mathrm{~d}$ & $0.22 \pm 0.002 \mathrm{a}$ \\
\hline $\mathrm{Cd}+\mathrm{B}$ & $2.54 \pm 0.02 \mathrm{~d}$ & $0.72 \pm 0.006$ ef & $3.26 \pm 0.026 \mathrm{e}$ & $3.53 \pm 0.015 b$ & $0.15 \pm 0.001 \mathrm{~d}$ \\
\hline $\mathrm{Cd}+\mathrm{Bc}$ & $2.53 \pm 0.02 \mathrm{~d}$ & $0.70 \pm 0.008 \mathrm{f}$ & $3.23 \pm 0.027 \mathrm{e}$ & $3.63 \pm 0.027 b$ & $0.15 \pm 0.001 \mathrm{~d}$ \\
\hline $\mathrm{Cd}+\mathrm{B}+\mathrm{Bc}$ & $2.66 \pm 0.01 \mathrm{c}$ & $0.74 \pm 0.004 \mathrm{e}$ & $3.39 \pm 0.011 \mathrm{~d}$ & $3.61 \pm 0.030 \mathrm{~b}$ & $0.16 \pm 0.002 \mathrm{~d}$ \\
\hline $\mathrm{LSD} \leq 0.01$ & 0.079 & 0.038 & 0.090 & 0.203 & 0.010 \\
\hline
\end{tabular}

Different small letters in the column indicated that the means are significantly different from each other at $p \leq 0.05$.

Table 2. Influence of the individual and combined applications of boron and biochar on the enzymatic antioxidants of wheat leaves under cadmium stress.

\begin{tabular}{ccccc}
\hline Treatments & $\begin{array}{c}\text { Superoxide } \\
\text { Dismutase (Unit } \\
\mathbf{m g}^{-\mathbf{1}} \text { Protein) }\end{array}$ & $\begin{array}{c}\text { Catalase } \\
\text { (Unit } \mathbf{~ m g}^{-\mathbf{1}} \text { Protein) }\end{array}$ & $\begin{array}{c}\text { Peroxidase } \\
\text { (Unit } \mathbf{~ m}^{-\mathbf{1}} \text { Protein) }\end{array}$ & $\begin{array}{c}\text { Ascorbate Peroxidase } \\
\text { (Unit mg }\end{array}$ \\
\hline Control $(\mathrm{ck})$ & $76.50 \pm 1.28 \mathrm{~g}$ & $9.38 \pm 0.17 \mathrm{~d}$ & $6.50 \pm 0.117 \mathrm{~d}$ & $0.94 \pm 0.051 \mathrm{~d}$ \\
\hline Cadmium $(\mathrm{Cd})$ & $123.60 \pm 2.73 \mathrm{~d}$ & $15.02 \pm 0.14 \mathrm{~b}$ & $9.30 \pm 0.098 \mathrm{c}$ & $1.79 \pm 0.048 \mathrm{c}$ \\
\hline Boron $(\mathrm{B})$ & $89.53 \pm 2.45 \mathrm{f}$ & $11.31 \pm 0.44 \mathrm{c}$ & $7.38 \pm 0.061 \mathrm{~d}$ & $1.02 \pm 0.024 \mathrm{~d}$ \\
\hline Biochar $(\mathrm{Bc})$ & $94.55 \pm 1.57 \mathrm{f}$ & $10.28 \pm 0.57 \mathrm{~cd}$ & $7.03 \pm 0.070 \mathrm{~d}$ & $1.04 \pm 0.027 \mathrm{~d}$ \\
\hline $\mathrm{B}+\mathrm{Bc}$ & $105.27 \pm 2.58 \mathrm{e}$ & $10.67 \pm 0.14 \mathrm{~cd}$ & $6.97 \pm 0.052 \mathrm{~d}$ & $1.12 \pm 0.046 \mathrm{~d}$ \\
\hline $\mathrm{Cd}+\mathrm{B}$ & $178.01 \pm 2.29 \mathrm{~b}$ & $16.34 \pm 0.31 \mathrm{~b}$ & $11.67 \pm 0.149 \mathrm{a}$ & $2.20 \pm 0.069 \mathrm{~b}$ \\
\hline $\mathrm{Cd}+\mathrm{Bc}$ & $163.47 \pm 3.03 \mathrm{c}$ & $15.33 \pm 0.72 \mathrm{~b}$ & $10.67 \pm 0.167 \mathrm{~b}$ & $1.93 \pm 0.023 \mathrm{c}$ \\
\hline $\mathrm{Cd}+\mathrm{B}+\mathrm{Bc}$ & $187.35 \pm 1.23 \mathrm{a}$ & $18.65 \pm 0.21 \mathrm{a}$ & $12.33 \pm 0.147 \mathrm{a}$ & $2.53 \pm 0.028 \mathrm{a}$ \\
\hline $\mathrm{LSD} \leq 0.01$ & 7.73 & 1.44 & 0.891 & 0.199 \\
\hline
\end{tabular}
$p \leq 0.05$.

\subsection{Lipid Peroxidation}

It was recorded that the application of only boron resulted in a $30.74 \%$ increase in $\mathrm{H}_{2} \mathrm{O}_{2}$ and $3.71 \%$ in soluble protein, with a $16.07 \%$ decline in malondialdehyde MDA content and $19.31 \%$ in electrolyte leakage as compared to the control conditions. Likewise, biochar application increased $\mathrm{H}_{2} \mathrm{O}_{2}$ by $20.24 \%$ and soluble protein by $16.64 \%$, while it reduced malondialdehyde MDA content by $8.35 \%$ and electrolyte leakage by $14.39 \%$ as compared to control in wheat plants. When the combination of boron and biochar was applied, it also enhanced $37.25 \% \mathrm{H}_{2} \mathrm{O}_{2}$ and soluble protein by $15.86 \%$ and reduced $4.25 \%$ malondialdehyde MDA content and $23.79 \%$ electrolyte leakage as compared to control. Although, when Cd stress was imposed, it increased $133.22 \% \mathrm{H}_{2} \mathrm{O}_{2}, 107.88 \%$ malondialdehyde MDA content, and $120.65 \%$ electrolyte leakage as compared to the control, but soluble protein content 
was reduced by $76.94 \%$ as compared to control. When these Cd-treated plants were treated with boron, it decreased $18.68 \% \mathrm{H}_{2} \mathrm{O}_{2}, 29.87 \%$ malondialdehyde MDA content, and $26.98 \%$ electrolyte leakage as compared to individual application of $\mathrm{Cd}$, while soluble protein content was increased by $90.24 \%$ as compared to individual application of $\mathrm{Cd}$ when boron was applied on Cd-treated plants. On the other hand, the application of biochar on Cdtreated plants resulted in $27.66 \%, 15.76 \%$, and $21.27 \%$ decreases in $\mathrm{H}_{2} \mathrm{O}_{2}$, malondialdehyde MDA content, and electrolyte leakage, respectively as compared to individual application of $\mathrm{Cd}$, while soluble protein content was increased by $100.0 \%$ as compared to individual application of $\mathrm{Cd}$. However, the combination of boron and biochar decreased the $34.94 \%$ $\mathrm{H}_{2} \mathrm{O}_{2}, 40.97 \%$ malondialdehyde contents MDA, and $38.51 \%$ electrolyte leakage as compared to individual application of $\mathrm{Cd}$, the soluble protein content was increased by $169.26 \%$ as compared to individual application of $\mathrm{Cd}$ (Table 3).

Table 3. The influence of the individual and combined applications of boron and biochar on hydrogen peroxide, malondialdehyde content, electrolyte leakage, and soluble protein of wheat leaves under cadmium stress.

\begin{tabular}{|c|c|c|c|c|}
\hline Treatments & $\begin{array}{l}\text { Hydrogen Peroxide } \\
\left(\mu \mathrm{mol} \mathrm{g}^{-1}\right)\end{array}$ & $\begin{array}{l}\text { Malondialdehyde } \\
\text { Content } \\
\left(\mu \mathrm{mol} \mathrm{g} \mathrm{g}^{-1}\right)\end{array}$ & $\begin{array}{l}\text { Electrolyte Leakage } \\
\qquad(\%)\end{array}$ & $\begin{array}{l}\text { Soluble Protein } \\
\quad\left(\mathrm{mgg}^{-1} \mathbf{f w}\right)\end{array}$ \\
\hline Control (ck) & $21.34 \pm 0.88 \mathrm{~g}$ & $12.69 \pm 0.30 \mathrm{e}$ & $35.77 \pm 0.75 \mathrm{~d}$ & $8.89 \pm 0.42 \mathrm{a}$ \\
\hline Cadmium (Cd) & $49.77 \pm 0.83 a$ & $26.38 \pm 0.68 \mathrm{a}$ & $78.93 \pm 0.89 a$ & $2.05 \pm 0.05 c$ \\
\hline Boron (B) & $27.90 \pm 0.54$ ef & $10.65 \pm 0.65 \mathrm{f}$ & $28.86 \pm 1.97 \mathrm{e}$ & $9.22 \pm 0.65 \mathrm{a}$ \\
\hline Biochar (Bc) & $25.66 \pm 0.29 \mathrm{f}$ & $11.63 \pm 0.27 \mathrm{ef}$ & $30.62 \pm 0.59 \mathrm{de}$ & $10.37 \pm 0.10 \mathrm{a}$ \\
\hline $\mathrm{B}+\mathrm{Bc}$ & $29.29 \pm 1.15 \mathrm{df}$ & $12.15 \pm 0.19$ ef & $27.26 \pm 1.10 \mathrm{e}$ & $10.30 \pm 0.68 \mathrm{a}$ \\
\hline $\mathrm{Cd}+\mathrm{B}$ & $40.47 \pm 0.79 b$ & $18.50 \pm 0.41 c$ & $57.63 \pm 2.02 b$ & $3.90 \pm 0.27 b$ \\
\hline $\mathrm{Cd}+\mathrm{Bc}$ & $36.00 \pm 0.57 c$ & $22.22 \pm 0.33 b$ & $62.14 \pm 2.19 b$ & $4.10 \pm 0.08 b$ \\
\hline $\mathrm{Cd}+\mathrm{B}+\mathrm{Bc}$ & $32.38 \pm 0.64 \mathrm{~d}$ & $15.57 \pm 0.40 \mathrm{~d}$ & $48.53 \pm 0.63 c$ & $5.52 \pm 0.12 b$ \\
\hline $\mathrm{LSD} \leq 0.01$ & 3.24 & 1.85 & 5.89 & 1.72 \\
\hline \multicolumn{5}{|c|}{$\begin{array}{l}\text { Different small letters in the column indicated that the means are significantly different from each other at } \\
p \leq 0.05 \text {. }\end{array}$} \\
\hline \multirow{2}{*}{\multicolumn{5}{|c|}{$\begin{array}{l}\text { Cadmium stress increased free proline by } 37.95 \% \text {, while it reduced soluble sugar } \\
\text { by } 56.25 \% \text { and total phenolic by } 64.13 \% \text { in wheat, as compared to the control. However, } \\
\text { when boron was applied to cadmium-stressed plants, it increased } 19.83 \% \text { total phenolic, } \\
43.95 \% \text { soluble sugar, and } 36.17 \% \text { total phenolic as compared to control, while biochar } \\
\text { application on cadmium-stressed plants enhanced } 9.26 \% \text { total phenolic, } 47.29 \% \text { soluble } \\
\text { sugar, and } 27.64 \% \text { total phenolic as compared to cadmium-stressed plants. The combination } \\
\text { of boron and biochar enhanced } 26.72 \% \text { total phenolic, } 53.95 \% \text { soluble sugar, and } 34.12 \% \\
\text { total phenolic as compared to cadmium-stressed plants (Table } 4 \text { ). } \\
\text { Table } 4 \text {. The influence of individual and combined applications of boron and biochar on the osmo- } \\
\text { protectants of wheat leaves under cadmium stress. }\end{array}$}} \\
\hline & & & & \\
\hline & Treatments & $\begin{array}{l}\text { Free Proline } \\
\quad\left(\mathrm{mg} \mathrm{g}^{-1}\right)\end{array}$ & $\begin{array}{l}\text { Soluble Sugar } \\
\quad\left(\mathrm{mg} \mathrm{g}^{-1}\right)\end{array}$ & $\begin{array}{l}\text { Total Phenolic } \\
\left(\mu \mathrm{mol} \mathrm{g}^{-1}\right)\end{array}$ \\
\hline & Control (ck) & $12.26 \pm 0.052 \mathrm{~d}$ & $7.50 \pm 0.45 \mathrm{~cd}$ & $4.79 \pm 0.17 \mathrm{bc}$ \\
\hline & Cadmium (Cd) & $19.76 \pm 0.015 c$ & $4.80 \pm 0.20 \mathrm{e}$ & $2.93 \pm 0.50 \mathrm{~d}$ \\
\hline & Boron (B) & $13.20 \pm 0.258 \mathrm{~d}$ & $8.47 \pm 0.37 \mathrm{bc}$ & $5.64 \pm 0.32 \mathrm{ab}$ \\
\hline & Biochar (Bc) & $13.03 \pm 0.619 \mathrm{~d}$ & $9.59 \pm 0.11 \mathrm{ab}$ & $6.28 \pm 0.41 \mathrm{a}$ \\
\hline
\end{tabular}


Table 4. Cont.

\begin{tabular}{cccc}
\hline Treatments & $\begin{array}{c}\text { Free Proline } \\
(\mathbf{m g ~ g} \mathbf{~})\end{array}$ & $\begin{array}{c}\text { Soluble Sugar } \\
\left(\mathbf{m g ~ g}^{-1}\right)\end{array}$ & $\begin{array}{c}\text { Total Phenolic } \\
\left(\boldsymbol{\mu} \mathbf{m o l} \mathbf{~ g}^{-\mathbf{1}}\right)\end{array}$ \\
\hline $\mathrm{B}+\mathrm{Bc}$ & $14.21 \pm 0.648 \mathrm{~d}$ & $9.92 \pm 0.30 \mathrm{a}$ & $6.22 \pm 0.55 \mathrm{a}$ \\
\hline $\mathrm{Cd}+\mathrm{B}$ & $23.68 \pm 0.787 \mathrm{ab}$ & $6.91 \pm 0.05 \mathrm{~d}$ & $3.99 \pm 0.15 \mathrm{~cd}$ \\
\hline $\mathrm{Cd}+\mathrm{Bc}$ & $21.59 \pm 0.799 \mathrm{bc}$ & $7.07 \pm 0.19 \mathrm{~d}$ & $3.74 \pm 0.06 \mathrm{~cd}$ \\
\hline $\mathrm{Cd}+\mathrm{B}+\mathrm{Bc}$ & $25.04 \pm 0.272 \mathrm{a}$ & $7.39 \pm 0.56 \mathrm{~cd}$ & $3.93 \pm 0.06 \mathrm{~cd}$ \\
\hline $\mathrm{LSD} \leq 0.01$ & 2.30 & 1.25 & 1.15 \\
\hline
\end{tabular}

Different small letters in the column indicated that the means are significantly different from each other at $p \leq 0.05$.

\section{Discussion}

The accumulation and toxicity of cadmium in crops can be reduced by lowering cadmium uptake in roots, as well as its translocation to above-ground plant parts.

\subsection{Morphological and Yield Traits}

From the results of this study, it was revealed that after addition of biochar in Cdcontaminated soil, morphological and yield traits were improved as compared to the soil where biochar was not added (Figure 1). This enhancement in different morphological as well as yield traits might be accredited to the nourishing significance of biochar that enhances soil fertility and productivity. Another possible reason for this improvement is attributed to its internal capacity to enhance organic mineralization and increase crop growth, as well as yields [37,38]. Above all, biochar acts as a buffer and is a source of important plant nutrients in a sufficient quantity availability which markedly boosts crop's productivity [39]. These findings were established because of a noticeable reduction in the phytoavailability of cadmium in soil amended with biochar, hence hindering plant's uptake of $\mathrm{Cd}$, which might have enhanced the ability of soil adsorption in biochar-amended soil. It has been reported that biochar has the ability to increase soil acidity and can improve the metal and basic nutrient availability from soil solutions that have an ability to reduce metal toxicity and, ultimately, improve crop growth and yield. Bashir et al. [40] reported in one previous study that the application of biochar in cadmium-polluted soils can proficiently overcome nutrient losses through leaching and volatilization, which is a vital factor in increasing soil fertility status and plant growth and yield.

The findings of our research depicted that the use of B application enhanced yield parameters due to its positive effects on plant growth (Figure 1). Lower yields of cadmiumstressed plants might be reasoned to the fast reduction in photosynthetic contents and assimilates. Hence, the movement of food assimilates from stem to grain is the main source, as well as a limiting factor for growth and development, and for reduction, in yields. Clemens et al. [41] showed that cadmium stress lowers plant growth first during the osmotic stress phase and, eventually, induces leaf senescence during the toxicity phase when more $\mathrm{Cd}$ is accumulated in leaves during transpiration. Ziaeyan and Rajaie [42] reported that the application of boron markedly enhanced plant biological yield, grain yield, 100-grain weight, number of grains per spike, and boron concentration in the tissues of plants grown under higher $\mathrm{Cd}$-accumulated conditions. Boron, as an integral micronutrient, plays vital role in enhancing pollen grain germination and pollen tube enlargement, fruit set percentage, and, finally, yield. Boron is responsible for stimulating cell division, biosynthesis, and translocation of sugars, water, and nutrient uptake [43].

\subsection{Photosynthetic Traits}

Photosynthetic activity is the basic functional process responsible for the growth and development of plants, but due to cadmium toxicity and cadmium stress, photosynthetic pigments are decreased in crop plants $[44,45]$. So, this cadmium stress leads to drastic effects on net photosynthetic processes. Presently, it was reported that the application of 
exogenous cadmium lowered chlorophyll contents such as chl a, chl b, and carotenoid (Table 2). There was a decrease in carboxylase, ribose 1, phosphoenolpyruvate carboxylase, and 5-diphosphate carboxylase activities, which led to a reduction in photosynthetic pigments caused by cadmium toxicity. There was also an observation of the reduction in production of $\mathrm{H}_{2} \mathrm{O}_{2}$, which caused degradation of chlorophyll by an enzymatic action, hindered stomatal opening, and played a limiting function in the biochemical processes of crop plants, which ultimately lowered the accumulation of photosynthetic pigments [46]. From the present experiment's results, it was found that the use of biochar applications improved photosynthesis components and chlorophyll contents such as chl a, chl b, and carotenoid under cadmium toxicity or cadmium stress conditions (Table 2). This significant improvement was due to the reason that the application of biochar has a positive effect on the stabilization of heavy metals present in the soil, ameliorating the hindering impact of cadmium on photosynthetic processes and photosynthetic pigments, such as chlorophyll, production because of its porosity in structure, higher $\mathrm{CEC}$, higher $\mathrm{pH}$, and different surface complexities [47]. The results of this experiment depicted that the application of boron significantly improved wheat chlorophyll contents such as chlorophyll a, chlorophyll b, and carotenoid, even in the presence of cadmium stress (Table 2).

In many research article findings, boron is found to have ameliorating effects on the toxicity of heavy metals in various crop plants, though it is still unclear if boron can increase the resistance response of plants to heavy metals toxicity. Under cadmium toxicity, enhanced chlorophyll pigments might be due to B application because B is implicated in cell wall structure formation and cell wall functioning. B has the ability to connect borate complexes with several polyhydroxy compounds, including pectin assembly, glycosylinositol phosphoryl ceramides (GIPCs,) and rhamnogalacturonan-II (RG-II). Firstly, the cell wall of plants comes into contact with toxic heavy metals, being the outermost layer of a plant cell. The cell wall is the first respondent to heavy metal toxicity, as well as serving as a sink for toxic metals adsorption and accumulation [48]. Due to this active behavior and response of the cell wall, the accumulation of heavy metals is increased in the cell wall and the movement of heavy metals to protoplast is decreased. Different compounds present in the cell wall, such as certain carbohydrates and pectic sites, create immobilization of toxic metals by interconnecting heavy metal ions and hindering these compounds from entering into the cell's internal protoplasm. Cell walls can perform as a bio-sorbent for ameliorating the toxic impact of toxic heavy metals $[48,49]$.

\subsection{Antioxidant Enzyme Activities}

Presently, the results of this experiment showed that the application of exogenous cadmium caused stress and decreased the functions of various antioxidant enzymes, including SOD, CAT, $\mathrm{H}_{2} \mathrm{O}_{2}$, POD, and MDA, and electrolytic breakdown and leakage, as well as soluble proteins in wheat (Tables 3 and 4). This reduction was due to the reason that under cadmium stress, a greater number of ROS are formed. Those ROS can be significantly harmful to the functioning and metabolic processes of plants. Moreover, cadmium toxicity is also related to free radicals in membrane structures that lead to reductions in mobilization and the penetration of free ions in plant tissues, producing bigger quantities of MDA, and thus involving oxidative stress in plants, which eventually leads to a decline in antioxidant enzyme activities [50]. The use of biochar enhanced the processes of antioxidant enzymes and improved the response of plants against oxidative stress produced due to Cd [51].

Presently, in our results, the use of biochar improved the performance of antioxidant enzymes such as SOD, POD, and CAT, successfully ameliorating the adverse effects of Cd in wheat (Table 3). This positive effect is due to the reason that CAT activity is responsible for removing the impacts of toxicity of peroxides in plant cells, and superoxide dismutase (SOD) is the prime enzyme acting as a decomposer for superoxide radicals into $\mathrm{H}_{2} \mathrm{O}_{2}$. POD function in crop plants is to aid respiratory activities in plants and the changing of phenols to quinines for lowering the stress of heavy-metal-induced oxidative stress [52]. The plants can resist metal-induced stress by improving their health with the help of better 
antioxidant defense mechanisms and can eliminate active oxygen with the addition of various amendments. Furthermore, a decrease of $\mathrm{Cd}$ concentration in various parts of plants likewise enhances anti-ROS safety activities in crop plants. The antioxidant enzymatic activities or antioxidant defense systems contribute key functioning in plants in relation to the response to heavy metal toxicity and stress. Enhanced levels of antioxidant enzymatic reactions can significantly diminish deposited ROS in crop plants. Several research findings have suggested that boron (B) diminishes cadmium stress by triggering antioxidant enzyme systems in crops [53]. In rice crops, improved performance of antioxidant enzymes played a key role in the mechanisms of resistance due to the addition of B against Cd toxicity [16]. As far as current experiment findings have determined, $\mathrm{Cd}$ occurrence leads to greater levels of MDA, $\mathrm{O}^{-2}$, and $\mathrm{H}_{2} \mathrm{O}_{2}$, and increases the superoxide dismutase, catalase, and peroxidase functions to remove deposited reactive oxygen species in shoots. Surprisingly, the application of B under cadmium stress conditions worked to lower ROS deposition in shoots by triggering an antioxidant enzyme mechanism, relieving the lipid peroxidation of the cell membrane, and regulating the growth of wheat shoots (Table 3). This positive improvement in antioxidant enzyme activities might be due to the reason that boron, as a structural part, plays a role in building the cell wall structure and its components [18]. This cell wall act as the primary obstacle for plant cells exposed to contact with toxic heavy metals [54]. It performs an important function in enhancing plant's cadmium resistance through hindering $\mathrm{Cd}$ entry into plant cells and by adsorption of cadmium in cell wall components, which include cellulose, hemi cellulose, and pectin, and can chelate cadmium in the cell wall to lower the movement of cadmium into cells, and thus enhances antioxidant enzyme activities [55].

\subsection{Biochemical Traits}

From our experiment findings, it was depicted that Cd toxicity reduced soluble sugar, total phenolic, and proline. Biochar application effectively increased proline, total phenolic, and soluble sugar contents in wheat under CD stress (Table 4). Various primary and secondary metabolic products such as soluble sugars and total proline and phenolic compounds play a vital role in cell osmotic adjustments. During stressful conditions, proline accumulation is higher in cells, as reported in many research studies. The findings of our experiment are in line with the results reported by [56]. The enhancement of the osmo-protectants, i.e., soluble sugars, proline, and total phenolic, could be attributed to biochar addition as a soil amendment in increasing the meristematic activity, which results in accelerated cell division and enlargement that ultimately improves the activity of osmoprotectants like proline, soluble sugar, and total phenolic [57]. From the current study, it was exhibited that biochar improved the osmo-protectants under Cd stress (Table 4). This improvement might be attributed to biochar application, which has the ability to hold water alongside increased nutrient absorption. Moreover, it has also been undeniably established that biochar can boost dry matter production (root and leaves) as a result of its positive effect on osmo-protectants under Cd stress [58].

\section{Conclusions}

It was concluded that B and biochar, when applied together at a $5 \mathrm{~g} \mathrm{~kg}^{-1}$ and $50 \mathrm{~g} \mathrm{~kg}^{-1}$ rate, significantly improved wheat plant's photosynthetic pigments, enzymatic activities, lipid peroxidation, osmo-protectants, and morphological and yield traits under both normal conditions and Cd toxicity. Therefore, it is suggested that wheat's photosynthetic pigments, enzymatic activities, lipid peroxidation, osmo-protectants, and morphological yield traits can be improved through the combined application of B and biochar under heavy metal (Cd) toxicity with a rate of $5 \mathrm{~g} \mathrm{~kg}^{-1}$ and $50 \mathrm{~g} \mathrm{~kg}^{-1}$, respectively.

Supplementary Materials: The following are available online at https:/ /www.mdpi.com/article/10 .3390 /agronomy12020434/s1, Table S1: The chemical composition of rice straw biochar. 
Author Contributions: S.H. (Sajjad Hussain), J.Y., and A.S. designed the study and developed and drafted the manuscript. S.H. (Shabir Hussain), S.U. and M.C. gave technical support and helped in statistical analyses. S.H. (Sajjad Hussain), T.A. and F.N. performed the chemical analyses. A.A.-H., M.S.E., H.U.-R. and M.I. helped in draft-editing and grammatic correction. All authors have read and agreed to the published version of the manuscript.

Funding: This research was funded by the National Key Research and Development Program of China (2018YFD0800305), the Agricultural Science and Technology Innovation Program of Chinese Academy of Agricultural Science (2021-2022) and the research supporting project number RSP2021/219 at King Saud University, Riyadh, Saudi Arabia.

Institutional Review Board Statement: Not applicable.

Informed Consent Statement: Not applicable.

Data Availability Statement: Not applicable.

Acknowledgments: Compliments goes to the National Key Research and Development Program of China (2018YFD0800305), the Agricultural Science and Technology Innovation Program of Chinese Academy of Agricultural Science (2021-2022). The authors extend their appreciation to the Researchers Supporting Project number (RSP-2021/219), King Saud University, Riyadh, Saudi Arabia.

Conflicts of Interest: The authors declare that they have no conflicts of interest.

\section{References}

1. Anjum, S.A.; Tanveer, M.; Hussain, S.; Shahzad, B.; Ashraf, U.; Fahad, S.; Hassan, W.; Jan, S.; Khan, I.; Saleem, M.F.; et al. Osmoregulation and antioxidant production in maize under combined cadmium and arsenic stress. Environ. Sci. Pollut. Res. 2016, 23, 11864-11875. [CrossRef] [PubMed]

2. Fattahi, B.; Arzani, K.; Souri, M.K.; Barzegar, M. Effects of cadmium and lead on seed germination, morphological traits, and essential oil composition of sweet basil (Ocimumbasilicum L.). Ind. Crops Prod. 2019, 138, 111584. [CrossRef]

3. Cui, Y.; Wang, Q. Physiological responses of maize to elemental sulphur and cadmium stress. Plant Soil Environ. 2018, 52, 523-529. [CrossRef]

4. Yang, Y. Assessing cadmium exposure risks of vegetables with plant uptake factor and soil property. Environ. Pollut. 2018, 238, 263-269. [CrossRef]

5. Ismael, M.A.; Elyamine, A.M.; Moussa, M.G.; Cai, M.; Zhao, X.; Hu, C. Cadmium in plants: Uptake, toxicity, and its interactions with selenium fertilizers. Metallomics 2019, 11, 255-277. [CrossRef]

6. Yizhu, L.; Imtiaz, M.; Ditta, A.; Rizwan, M.S.; Ashraf, M.; Mehmood, S.; Aziz, O.; Mubeen, F.; Ali, M.; Elahi, N.N.; et al. Response of growth, antioxidant enzymes and root exudates production towards as stress in Pteris vittata and in Astragalus sinicus colonized by arbuscular mycorrhizal fungi. Environ. Sci. Pollut. Res. 2020, 27, 2340-2352. [CrossRef]

7. Khan, Z.S.; Rizwan, M.; Hafeez, M.; Ali, S.; Adrees, M.; Qayyum, M.F.; Khalid, S.; Rehman, M.Z.U.; Sarwar, M.A. Effects of silicon nanoparticles on growth and physiology of wheat in cadmium contaminated soil under different soil moisture levels. Environ. Sci. Pollut. Res. 2020, 27, 4958-4968. [CrossRef]

8. Thind, S.; Hussain, I.; Ali, S.; Hussain, S.; Rasheed, R.; Ali, B.; Hussain, H.A. Physiological and biochemical bases of foliar silicon-induced alleviation of cadmium toxicity in wheat. J. Soil Sci. Plant Nutr. 2020, 20, 2714-2730. [CrossRef]

9. Suriyagoda, L.D.B.; Dittert, K.; Lambers, H. Mechanism of arsenic uptake, translocation and plant resistance to accumulate arsenic in rice grains. Agric. Ecosyst. Environ. 2018, 253, 23-37. [CrossRef]

10. Bianucci, E.; Peralta, J.M.; Furlan, A.; Hernández, L.E.; Castro, S. Arsenic in wheat, maize, and other crops. In Arsenic in Drinking Water and Food; Srivastava, S., Ed.; Springer: Singapore, 2020; pp. 279-306.

11. Raza, A.; Habib, M.; Kakavand, S.N.; Zahid, Z.; Zahra, N.; Sharif, R.; Hasanuzzaman, M. Phytoremediation of Cadmium: Physiological, Biochemical, and Molecular Mechanisms. Biology 2020, 9, 177. [CrossRef]

12. Hansch, R.; Mendel, R.R. Physiological Functions of Mineral Micronutrients (Cu, Zn, Mn, Fe, Ni, Mo, B, Cl). Curr. Opin. Plant Biol. 2009, 12, 259-266. [CrossRef]

13. Shireen, F.; Nawaz, M.; Chen, C.; Zhang, Q.; Zheng, Z.; Sohail, H.; Bie, Z. Boron: Functions and Approaches to Enhance Its Availability in Plants for Sustainable Agriculture. Int. J. Mol. Sci. 2018, 19, 1856. [CrossRef]

14. Camacho-Cristóbal, J.J.; González-Fontes, A. Boron deficiency decreases plasmalemma H+-ATPase expression and nitrate uptake, and promotes ammonium assimilation into asparagine in tobacco roots. Planta 2007, 226, 443-451. [CrossRef]

15. Riaz, M.; Kamran, M.; Fang, Y.; Yang, G.; Rizwan, M.; Ali, S.; Zhou, Y.; Wang, Q.; Deng, L.; Wang, Y.; et al. Boron supply alleviates cadmium toxicity in rice (Oryza sativa L.) by enhancing cadmium adsorption on cell wall and triggering antioxidant defense system in roots. Chemosphere 2021, 266, 128938. [CrossRef]

16. Chen, D.; Chen, D.; Xue, R.; Long, J.; Lin, X.; Lin, Y.; Jia, L.; Zeng, R.; Song, Y. Effects of boron, silicon and their interactions on cadmium accumulation and toxicity in rice plants. J. Hazard. Mater. 2019, 367, 447-455. [CrossRef] 
17. Zhang, F.; Liu, M.; Li, Y.; Che, Y.; Xiao, Y. Effects of arbuscular mycorrhizal fungi, biochar and cadmium on the yield and element uptake of Medicago sativa. Sci. Total Environ. 2019, 655, 1150-1158. [CrossRef]

18. Wu, S.; Hu, C.; Tan, Q.; Xu, S.; Sun, X. Nitric oxide mediates molybdenum-induced antioxidant defense in wheat under drought stress. Front. Plant Sci. 2017, 8, 1085. [CrossRef]

19. Srivastava, H.M.; Günerhan, H.; Ghanbari, B. Exact traveling wave solutions for resonance nonlinear Schrödinger equation with intermodal dispersions and the Kerr law nonlinearity. Math. Methods Appl. Sci. 2019, 42, 7210-7221. [CrossRef]

20. Kumar, A.; Bhattacharya, T. Biochar: A sustainable solution. Environ. Dev. Sustain. 2021, 23, 6642-6680. [CrossRef]

21. Naeem, M.A.; Shabbir, A.; Amjad, M.; Abbas, G.; Imran, M.; Murtaza, B.; Tahir, M.; Ahmad, A. Acid treated biochar enhances cadmium tolerance by restricting its uptake and improving physio-chemical attributes in quinoa (Chenopodium quinoa Willd). Ecotoxicol. Environ. Saf. 2020, 191, 110-218. [CrossRef]

22. Ibrahim, I.A.; Emara, H.A.; Nower, A.A.; Abodiab, L. In vitro cultivation of potato plants. Int. J. Curr. Microbiol. Appl. 2016, 5, 858-868. [CrossRef]

23. Qayyum, M.F.; Abid, M.; Danish, S.; Saeed, M.K.; Ali, M.A. Effects of various biochars on seed germination and carbon mineralization in an alkaline soil. Pak. J. Agric. Sci. 2015, 51, 977-982.

24. Aron, D. Copper enzymes isolated chloroplasts, polyphenoloxidase in Beta vulgaris. Plant Physiol. 1949, 24, 1-15. [CrossRef]

25. Bradford, M.M. A rapid and sensitive method for the quantitation of microgram quantities of protein utilizing the principle of protein-dye binding. Anal. Biochem. 1976, 72, 248-254. [CrossRef]

26. Hamilton, P.B.; Van-Slyke, D.D. Amino acid determination with ninhydrin. J. Biol. Chem. 1943, 150, 231-233. [CrossRef]

27. Yemm, E.; Willis, A.J. The estimation of carbohydrate in plant extracts by Anthrone. Biochem. J. 1954, 57, 508-514. [CrossRef]

28. Julkunen-Titto, R. Phenolic constituents in the leaves of northern willows: Methods for the analysis of certain phenolics. J. Agric. Food Chem. 1985, 33, 213-217. [CrossRef]

29. Dhindsa, R.S.; Dhindsa, P.P.; Thorpe, T.A. Leaf senescence correlated with increased levels of membrane permeability and lipid-peroxidation and decreased levels of superoxide dismutase and catalase. J. Exp. Bot. 1980, 32, 93-101. [CrossRef]

30. Giannopolitis, C.N.; Reis, S.K. Superoxide dismutase I. Occurrence in higher plants. Plant Physiol. 1997, 59, 309-314. [CrossRef]

31. Polle, A.; Otter, T.; Seifert, F. Apoplastic peroxidases and lignification in needles of Norway Spruce Piceaabies L. Plant Physiol. 1994, 106, 53-60. [CrossRef]

32. Aebi, H. Catalase in vitro. Methods Enzymol. 1984, 105, 121-126. [PubMed]

33. Velikova, V.; Yordanov, I.; Edreva, A. Oxidative stress and some antioxidant systems in acid rain-treated bean plants. Protective role of exogenous polyamines. Plant Sci. 2000, 151, 59-66. [CrossRef]

34. Hodges, D.M.; DeLong, J.M.; Forney, C.F.; Prange, R.K. Improving the thiobarbituric acid-reactive-substances assay for estimating lipid peroxidation in plant tissues containing anthocyanin and other interfering compounds. Planta 1999, 207, 604-611. [CrossRef]

35. Bates, L.S.; Waldren, R.P.; Teare, I.D. Rapid determination of free proline for water stress studies. Plant Soil 1973, 39, 205-207. [CrossRef]

36. Dionisio-Sese, M.L.; Tobita, S. Antioxidant responses of rice seedlings to salinity stress. Plant Sci. 1998, 135, 1-9. [CrossRef]

37. Rehman, M.Z.; Khalid, H.; Akmal, F.; Ali, S.; Rizwan, M.; Qayyum, M.F.; Iqbal, M.; Khalid, M.U.; Azhar, M. Effect of limestone, lignite and biochar applied alone and combined on cadmium uptake in wheat and rice under rotation in an effluent irrigated field. Environ. Pollut. 2017, 227, 560-568. [CrossRef]

38. Bashir, S.; Rehman, M.; Yousaf, M.; Salam, A.; Gulshan, A.B.; Iqbal, J.; Aziz, I.; Azeem, M.; Rukh, S.; Asghar, R.M.A. Comparative efficiency of wheat straw and sugarcane bagasse biochar reduces the cadmium bioavailability to spinach and enhances the microbial activity in contaminated soil. Int. J. Phytoremediation 2019, 21, 1098-1103. [CrossRef]

39. Ali, I.; Ullah, S.; He, L.; Zhao, Q.; Iqbal, A.; Wei, S.; Shah, T.; Ali, N.; Bo, Y.; Adnan, M.; et al. Combined application of biochar and nitrogen fertilizer improves rice yield, microbial activity and N-metabolism in a pot experiment. Peer J. 2020, 8, e10311. [CrossRef]

40. Bashir, S.; Hussain, Q.; Akmal, M.; Riaz, M.; Hu, H.Q.; Ijaz, S.S.; Iqbal, M.; Abro, S.; Mehmood, S.; Ahmad, M. Sugarcane bagasse-derived biochar reduces the cadmium and chromium bioavailability to mash bean and enhances the microbial activity in contaminated soil. J. Soils Sediments 2018, 18, 874-886. [CrossRef]

41. Clemens, S.; Aarts, M.G.M.; Thomine, S.; Verbruggen, N. Plant science: The key to preventing slow cadmium poisoning. Trends Plant Sci. 2013, 18, 92-99. [CrossRef]

42. Ziaeyan, A.H.; Rajaie, M. Combined effect of zinc and boron on yield and nutrients accumulation in corn. Int. J. Plant Prod. 2009, 3, 33-45.

43. Ahmed, W.; Niaz, A.; Kanwal, S.; Rahmatullah, A. Role of boron in plant growth. J. Agric. Res. 2009, 47, 329-338.

44. Xu, C.Y.; Hosseini-Bai, S.; Hao, Y.; Rachaputi, R.C.; Wang, H.; Xu, Z.; Wallace, H. Effect of biochar amendment on yield and photosynthesis of peanut on two types of soils. Environ. Sci. Pollut. Res. 2015, 22, 6112-6125. [CrossRef]

45. Li, L.; Ai, S.; Li, Y.; Wang, Y.H.; Tang, M.D. Exogenous silicon mediates alleviation of cadmium stress by promoting photosynthetic activity and activities of antioxidative enzymes in rice. J. Plant Growth Regul. 2018, 37, 602-611. [CrossRef]

46. Deng, X.P.; Cheng, Y.J.; Wu, X.B.; Kwak, S.S.; Chen, W.; Egrinya, A. Exogenous hydrogen peroxide positively influences root growth and metabolism in leaves of sweet potato seedlings. Aust. J. Crop Sci. 2012, 6, 1572-1578.

47. Kamran, M.; Malik, Z.; Parveen, A.; Huang, L.; Riaz, M.; Bashir, S.; Mustafa, A.; Abbasi, G.H.; Xue, B.; Ali, U. Ameliorative effects of biochar on rapeseed (Brassica napus L.) growth and heavy metal immobilization in soil irrigated with untreated wastewater. J. Plant Growth Regul. 2020, 39, 266-281. [CrossRef] 
48. Parrotta, L.; Guerriero, G.; Sergeant, K.; Cai, G.; Hausman, J.F. Target or barrier? The cell walls of early-and later-diverging plants vs. cadmium toxicity: Differences in the response mechanisms. Front. Plant Sci. 2015, 6, 133. [CrossRef]

49. Voxeur, A.; Fry, S.C. Glycosylinositolphosphorylceramides (GIPCs) from Rosa cell cultures are boron-bridged in the plasma membrane and form complexes with rhamnogalacturonan II. Plant J. 2014, 79, 139-149. [CrossRef]

50. Muszyńska, E.; Labudda, M.; Różańska, E.; Hanus-Fajerska, E.; Koszelnik-Leszek, A. Structural, physiological and genetic diversification of Silene vulgaris ecotypes from heavy metal-contaminated areas and their synchronous in vitro cultivation. Planta 2019, 249, 1761-1778. [CrossRef]

51. Novak, J.M.; Ippolito, J.A.; Watts, D.W.; Sigua, G.C.; Ducey, T.F.; Johnson, M.G. Biochar compost blends facilitate switchgrass growth in mine soils by reducing $C d$ and Zn bioavailability. Biochar 2019, 1, 97-114. [CrossRef]

52. Cheng, J.; Qiu, H.; Chang, Z.; Jiang, Z.; Yin, W. The effect of cadmium on the growth and antioxidant response for freshwater algae Chlorella vulgaris. Springerplus 2016, 5, 1290. [CrossRef]

53. Riaz, M.; Yan, L.; Wu, X.; Hussain, S.; Aziz, O.; Wang, Y.; Imran, M.; Jiang, C. Boron alleviates the aluminum toxicity in trifoliate orange by regulating antioxidant defense system and reducing root cell injury. J. Environ. Manag. 2018, 208, 149-158. [CrossRef]

54. Gutsch, A.; Keunen, E.; Guerriero, G.; Renaut, J.; Cuypers, A.; Hausman, J.F.; Sergeant, K.; Luo, Z.B. Long-term cadmium exposure influences the abundance of proteins that impact the cell wall structure in Medicago sativa stems. Plant Biol. 2018, 20, 1023-1035. [CrossRef]

55. Peng, J.; He, Y.; Ye, L.; Shen, T.; Liu, F.; Kong, W. Moisture influence reducing method for heavy metals detection in plant materials using laser-induced breakdown spectroscopy: A case study for chromium content detection in rice leaves. Anal. Chem. 2017, 89, 7593-7600. [CrossRef]

56. Noreen, S.; Faiz, S.; Akhter, M.S.; Shah, K.H. Influence of Foliar Application of Osmoprotectants to Ameliorate Salt Stress in Sunflower (Helianthus annuus L.). Sarhad J. Agric. 2019, 35, 1316-1325. [CrossRef]

57. Wang, Y.M.; Gao, Q.; Xue, L.H.; Yang, L.Z.; Li, H.X.; Feng, Y.F. Effects of different biochar application patterns on rice growth and yield. J. Agric. Resour. Environ. 2018, 1, 58-65.

58. Hasanuzzaman, M.; Banerjee, A.; BorhannuddinBhuyan, M.H.M.; Roychoudhury, A.; Al Mahmud, J.; Fujita, M. Targeting glycinebetaine for abiotic stress tolerance in crop plants: Physiological mechanism, molecular interaction and signaling. Phyton 2019, 88, 185-221. [CrossRef] 